Journal of Health Science
(Jurnal Ilmu Kesehatan)
$\frac{\text { https://www.ejournalwiraraja.com/index.php/JIK }}{2356-5284 \text { (Print) }}$

\title{
Pemahaman Tentang Hak Dan Kewajiban Peserta BPJS Kesehatan Di Puskesmas Ganding Sumenep
}

\author{
Moh. Jonaidy Prasetiawan', Eko Mulyadi², Sugesti Aliftitah ${ }^{3}$ \\ 1,2Program Studi Keperawatan, Universitas Wiraraja, Sumenep, Indonesia \\ ${ }^{3}$ Program Studi Ners, Universitas Wiraraja, Sumenep, Indonesia \\ 1'moh.jonaidy@gmail.com,,Eko.mulyadi@wiraraja.ac.id,’3purples_lovers@yahoo.co.id
}

\begin{tabular}{ll}
\hline Informasi artikel & ABSTRAK \\
\hline Sejarah artikel: & Banyaknya peserta BPJS Kesehatan yang belum mengerti perihal hak dan \\
Diterima:08-11-2019 & kewajiban peserta BPJS Kesehatan, membuat para petugas kesehatan di \\
Publikasi:28-11-2019 & fasilitas kesehatan sering konflik dengan pasien maupun keluarga pasien. \\
& $\begin{array}{l}\text { Penelitian ini dilakukan untuk menggambarkan pemahaman tentang hak dan } \\
\text { kewajiban peserta BPJS Kesehatan. }\end{array}$
\end{tabular}
Metode dalam penelitian ini adalah penelitian deskriptif kualitatif, penelitian ini dimaksudkan untuk menyelidiki keadaan, kondisi atau hal lain-lain, yang

Kata kunci:

Hak,

Kewajiban,

Sosialisasi, BPJS Kesehatan

hasilnya dipaparkan dalam bentuk laporan penelitian. Kurangnya pemahaman peserta BPJS Kesehatan disebabkan belum adanya informasi yang jelas, benar, terperinci dan detail perihal peraturan, pembiayaan, hak dan kewajibannya, sanksi jika terlambat membayar iuran, faskes tujuan, rujukan berjenjang, pelayanan gawat darurat, cara menyampaikan keluhan, maupun perihal pelayanan kesehatan apa saja yang bisa dan tidak bisa didapatkan.

Pihak BPJS Kesehatan melakukan sosialisasi secara pasif, yaitu hanya melakukan sosialisasi jika diundang datang oleh pihak yang berkepentingan. Menurut UU No. 08 tahun 1999 tentang Perlindungan Konsumen BPJS Kesehatan selaku pelaku usaha berkewajiban memberikan informasi dan sosialisasi yang jelas, benar, dan jujur perihal produk barang atau dan jasa yang akan diberikan, tidak boleh sampai menimbulkan penafsiran, harus jelas, terperinci, dan detail.

Key word:

Rights, Responsibilities, Socialization, BPJS Kesehatan

\begin{abstract}
The large number of BPJS Kesehatan participants who did not understand the rights and responsibilities of BPJS Kesehatan participants, made medical workers in health facilities often had conflict with patients and patient's family.

This research was conducted to describe the understanding about the rights and obligations of BPJS Kesehatan participants. The method in this research is qulitative descriptive research, this research is intended to investigate the condition, condition or other matters, which result presented in the form of research report. Lack of understanding of BPJS Kesehatan participants due to the absence of clear, correct, detailed and detail information regarding regulations, financing, rights and obligations, sanctions if late dues, health facility destinations, tiered referral, emergency services, how to submit complaints, or concerning health services anything that can and can not be obtained.

BPJS Kesehatan socializes passively, which is only doing socialization if invited to come by interested parties. According to Law No. 08 of 1999 on Consumer Protection, BPJS Kesehatan as a business actor is obliged to provide information and socialization that is clear, true and honest about the product of goods or and services to be provided, should not cause the interpretation, must be clear, detailed, and detail
\end{abstract}

\author{
Pendahuluan \\ Banyaknya peserta BPJS Kesehatan yang \\ belum mengerti perihal hak dan kewajiban \\ peserta BPJS Kesehatan, membuat para
}

petugas kesehatan di fasilitas kesehatan sering konflik dengan pasien maupun keluarga pasien. Kondisi ini diperburuk dengan banyaknya kesenjangan antara 
peraturan yang diterapkan BPJS Kesehatan dengan harapan peserta BPJS Kesehatan terhadap pelayanan yang ingin mereka dapatkan setelah ikut menjadi anggota BPJS Kesehatan. Masalah serupa juga banyak ditemukan pada fasilitas kesehatan lain yang bekerja sama dengan BPJS Kesehatan. Sementara pemerintah mencanangkan program ini agar terlaksana dengan sukses, yaitu seluruh lapisan masyarakat Indonesia terjamin kesehatannya dengan ikut serta menjadi anggota BPJS Kesehatan.

Menurut Info BPJS (2016), keikutsertaan masyarakat Indonesia dalam program Jaminan Kesehatan Nasional (JKN) melalui Badan Penyelenggara Jaminan Sosial (BPJS) Kesehatan di bulan Maret 2016 mencapai 163.327.183 peserta. Dan menurut Wicaksono (2016), di Jatim dalam program Jaminan Kesehatan Nasional (JKN) melalui Badan Penyelenggara Jaminan Sosial (BPJS) Kesehatan sampai dengan triwulan I 2016 mencapai 22.622.049 peserta, jumlah ini meningkat dari tahun 2014.

Di tingkat pertama layanan kesehatan, BPJS Kesehatan memperkuat jaringan fasilitas kesehatan tingkat pertama (FKTP) dengan membangun aplikasi Primary Care (P-Care). P-Care merupakan sistem informasi pelayanan pasien peserta BPJS Kesehatan, berbasis komputer dan online via internet. Pada dasarnya, P-Care mempunyai 2 fungsi besar yaitu pendaftaran oleh petugas pendaftaran dan pelayanan pasien dimana entri data dilaksanakan oleh dokter atau petugas balai pengobatan. (BPJS, 2014:7). Dan berdasarkan laporan p-care pada bulan Mei tahun 2017 jumlah pasien terdaftar pada Fasilitas Kesehatan Tingkat Pertama di Puskesmas Ganding Kabupaten Sumenep mencapai 24.133 peserta. Banyaknya masyarakat Indonesia yang sudah ikut serta dalam Jaminan Kesehatan Nasional ini, tidak menutup kemungkinan banyak ditemukan masalah yang serupa, dialami oleh fasilitas kesehatan lain dalam melakukan pelayanan kesehatan.

\section{Metode Penelitian}

Jenis penelitian yang digunakan dalam penelitian ini adalah penelitian deskriptif kualitatif. Penelitian ini dilakukan di Puskesmas Ganding Kabupaten Sumenep pada bulan November sd. Desember 2017. Teknik pengambilan sampel dalam penelitian ini menggunakan metode purposive sampling. Sampel di dalam penelitian kualitatif tidak dinamakan responden tetapi sebagai narasumber, atau partisipan, informan, teman dan guru dalam penelitian. Informan ditetapkan PBI sebanyak 4 orang, non-PBI dari pekerja mandiri sebanyak 4 orang, non-PBI dari PNS, TNI, POLRI sebanyak 4 orang sehubungan keterbatasan peneliti.

Dalam penelitian ini, peneliti menggunakan teknik coding sebagai teknik analisa data yang ada. Verifikasi data dalam penelitian ini menggunakan metode triangulasi. Metode triangulasi dengan menggunakan wawancara dan obervasi atau pengamatan untuk mengecek kebenarannya. Selain itu, peneliti juga bisa menggunakan informan yang berbeda untuk mengecek kebenaran informasi tersebut. Melalui berbagai perspektif atau pandangan diharapkan diperoleh hasil yang mendekati kebenaran.

\section{Hasil Penelitian \\ 1. Peserta Tidak Tahu tentang Aturan Peserta BPJS Kesehatan}

Berdasarkan wawancara mendalam yang dilakukan peneliti terhadap informan mengenai aturan peserta BPJS Kesehatan diperoleh hasil seluruh informan memberikan jawaban tidak tahu tentang aturan peserta BPJS Kesehatan. Hasil analisis tema menggunakan aplikasi $N V I V O$ terhadap jawaban Peserta BPJS Kesehatan diperoleh kata yang paling dominan adalah kata tahu, saya, tidak dan belum. Adapun ketidaktahuan peserta terhadap peraturan BPJS Kesehatan karena belum ada yang menjelaskan kepada mereka, sepengetahuan mereka kartu BPJS tersebut dapat digunakan untuk berobat gratis.

\section{Peserta Tidak Tahu Pembiayaan Peserta BPJS Kesehatan}

Hasil wawancara dengan peserta BPJS Kesehatan hampir seluruhnya tidak tahu terhadap pembiayaan peserta BPJS Kesehatan. Hasil analisis tema menggunakan aplikasi NVIVO terhadap jawaban Peserta BPJS Kesehatan diperoleh kata yang paling dominan adalah kata tidak, saya, tahu, ada, dan pembiayaan. Menurut peserta PBI setiap bulannya mereka tidak pernah bayar, dan belum pernah ada yang menagih. Sedangkan pada aparatur negara seperti pada PNS, TNI, dan POLRI mereka tahu pembiayaannya melalui potong gaji, tetapi mereka tidak tahu berapa besararan potongan gajinya. Dan untuk peserta Non PBI Mandiri mereka dapat langsung 
menjawab berapa besaran iuran yang harus dibayarkan setiap bulannya.

\section{Peserta Tidak Tahu Hak dan Kewajiban Peserta BPJS Kesehatan}

Berdasarkan wawancara mendalam yang dilakukan peneliti terhadap informan mengenai hak dan kewajiban peserta BPJS Kesehatan diperoleh hasil peserta tidak mengetahui kewajiban mereka sebagai peserta BPJS Kesehatan. Hasil analisis tema menggunakan aplikasi NVIVO terhadap jawaban Peserta BPJS Kesehatan diperoleh kata yang paling dominan adalah kata saya, tahu, tidak, dan sakit. Menurut peserta PBI haknya jika sakit dapat berobat gratis, sedangkan kewajibannya mereka tidak tahu. Pada peserta Non-PBI haknya jika berobat gratis, dan kewajibannya membayar iuran.

\section{Peserta Tidak Tahu Sanksi jika Terlambat Membayar Iuran}

Berdasarkan wawancara yang dilakukan peneliti terhadap informan mengenai sanksinya jika terlambat membayar iuran diperoleh hasil peserta BPJS Kesehatan tidak tahu sanksinya jika terlambat membayar iuran. Hasil analisis tema menggunakan aplikasi NVIVO terhadap jawaban Peserta BPJS Kesehatan diperoleh kata yang paling dominan adalah kata terlambat, tidak, sanksinya, iuran, membayar, dan tahu. Pada peserta PBI dan Non PBI Mandiri, mereka langsung menjawab tidak tahu. Dan pada peserta aparatur negara seperti pada PNS, TNI, dan POLRI mereka juga menjawab tidak tahu, karena BPJS tidak pernah minta langsung, langsung potong gaji.

\section{Peserta Tidak Tahu tentang Faskes} Tujuan, Rujukan Berjenjang, dan Pelayanan Gawat Darurat

Hasil wawancara dengan peserta BPJS Kesehatan diperoleh hasil lebih dari separuh informan tahu tentang persyaratan yang harus dibawa, tetapi hampir seluruhnya tidak tahu mengenai faskes, pelayanan rujukan, dan pelayanan gawat darurat. Hasil analisis tema menggunakan aplikasi NVIVO terhadap jawaban Peserta BPJS Kesehatan diperoleh kata yang paling dominan adalah kata saya, tidak, faskes, tahu, darurat, gawat, kartu, cara, dan mendapatkan. Hampir seluruh peserta mengetahui cara mendapatkan pelayanan, yaitu dengan membawa kartu BPJS Kesehatan dan kartu identitas diri. Tetapi hampir seluruhnya belum mengeahui cara mendapatkan rujukan misalkan perlu dirujuk ke Surabaya. Peserta juga tidak tahu faskes itu apa, menurut mereka berobat dimana saja pasti bisa, misalkan mereka berobat di faskes lain yang tidak terdaftar nama mereka. Peserta juga tidak tahu misalkan mereka bepergian ke luar kota, dan dalam perjalanan mereka sakit, apakah bisa menggunakan kartu BPJS Kesehatan tersebut atau tidak.

\section{Peserta Merasakan Manfaat Menjadi Peserta BPJS Kesehatan}

Berdasarkan wawancara mendalam yang dilakukan peneliti terhadap informan mengenai apa saja manfaat BPJS Kesehatan diperoleh hasil seluruh peserta menjawab merasa bermanfaat menjadi peserta BPJS Kesehatan. Hasil analisis tema menggunakan aplikasi NVIVO terhadap jawaban Peserta BPJS Kesehatan diperoleh kata yang paling dominan adalah kata manfaatnya, saya, ada, dan bermanfaat. Adapun manfaat yang diperoleh peserta diantaranya meringankan biaya pengobatan, menunjang keuangan peserta untuk kesehatan mereka, mendapatkan pelayanan kesehatan yang gratis tanpa pungutan, dan menyimpan uang sehingga tidak keluar uang pada saat sakit.

\section{Peserta Tidak Tahu kepada Siapa Menyampaikan Keluhan}

Berdasarkan wawancara mendalam yang dilakukan peneliti terhadap informan mengenai jika terdapat kendala atau masalah perihal pemanfaatan pelayanan kepada siapa menyampaikan keluhan diperoleh hasil berupa lebih dari separuh dari peserta BPJS Kesehatan tidak tahu kepada siapa menyampaikan keluhan. Hasil analisis tema menggunakan aplikasi NVIVO terhadap jawaban Peserta BPJS Kesehatan diperoleh kata yang paling dominan adalah kata keluhan, saya, tidak, dan tahu. Pada peserta PBI jika terdapat keluhan, mereka menyampaikannya kepada kepala dusun atau kepala desa nya masing-masing. Sedangkan pada peserta Non PBI menyampaikan keluhannya kepada instansi satuan masing-masing, seperti Tn. BS menyampaikan keluhannya ke Polres. Hanya sebagian kecil dari informan yang mengetahui jika ada keluhan menyampaikannya ke pihak BPJS Kesehatan. 
8. Untuk Mengurangi Biaya Pengobatan Menjadi Alasan Peserta Ikut BPJS Kesehatan

Berdasarkan wawancara mendalam yang dilakukan peneliti terhadap informan mengenai alasan anda ikut BPJS Kesehatan diperoleh hasil lebih dari separuh peserta mengatakan agar mengurangi biaya pengobatan pada saat sakit. Hasil analisis tema menggunakan aplikasi NVIVO terhadap jawaban Peserta BPJS Kesehatan diperoleh kata yang paling dominan adalah kata ikut, kesehatan, alasan, tidak, saya, sakit, jaga, dan mampu. Alasan peserta PBI karena mereka tidak mampu untuk biaya berobat. Dan alasan untuk peserta Non PBI menyimpan uang untuk jaga-jaga kesehatan saat sakit.

\section{Tidak Dipungut Biaya Menjadi Alasan} Kepuasan Peserta BPJS Kesehatan

Berdasarkan wawancara yang dilakukan peneliti terhadap informan mengenai kepuasan menjadi peserta BPJS Kesehatan diperoleh hasil hampir seluruh informan mengatakan puas menjadi peserta BPJS Kesehatan. Hasil analisis tema menggunakan aplikasi NVIVO terhadap jawaban Peserta BPJS Kesehatan diperoleh kata yang paling dominan adalah kata puas, tidak, saya, biaya, dan dipungut. Informan merupakan peserta BPJS Kesehatan yang telah memiliki pengalaman menggunakan pelayanan kesehatan. Kepuasan yang mereka sampaikan berdasarkan pengalaman yang mereka alami. Kepuasan menjadi peserta BPJS Kesehatan menurut para informan diantaranya tidak dipungut biaya saat berobat, tidak ada perbedaan pelayanan antara pasien umum dengan pasien BPJS Kesehatan, pelayanan yang cepat dan mudah, dan terjaminnya keberhasilan pengobatan.

\section{Peserta Berminat untuk Mengajak Teman atau Keluarga Untuk Ikut BPJS Kesehatan}

Berdasarkan wawancara mendalam yang dilakukan peneliti terhadap informan mengenai minat mereka untuk merekomendasikan atau mengajak teman atau keluarga untuk ikut BPJS Kesehatan diperoleh hasil lebih dari separuh informan berminat untuk mengajak teman atau keluarga untuk ikut BPJS Kesehatan. Hasil analisis tema menggunakan aplikasi NVIVO terhadap jawaban Peserta BPJS Kesehatan diperoleh kata yang paling dominan adalah kata saya, mengajak, ikut, alasan, dan karena. Alasan mereka untuk mengajak antara lain karena berobat tanpa dipungut biaya, banyak teman dan keluarga mereka yang tergolong belum mampu, pelayanan yang cepat dan mudah, tidak mengeluarkan biaya saat sakit, menyimpan uang untuk menjaga kesehatan saat sakit, dan pembiayaan iuran yang sangat kecil.

\section{Teman dan Keluarga Berpendapat Baik tentang BPJS Kesehatan}

Berdasarkan wawancara mendalam yang dilakukan peneliti terhadap informan mengenai pendapat teman atau keluarga tentang BPJS Kesehatan diperoleh hasil hampir seluruh informan menyatakan pelayanannya baik. Hasil analisis tema menggunakan aplikasi NVIVO terhadap jawaban Peserta BPJS Kesehatan diperoleh kata yang paling dominan adalah kata baik, saya, anggota, biaya, dan enak. Adapun alasan teman dan keluarga terhadap BPJS Kesehatan adalah pengalaman tetangga mereka yang menceritakan bahwa pernah rawat inap di Puskesmas Ganding tidak dipungut biaya apapun, menguntungkan, tidak dipersulit, gratis, pelayanan cepat dan bagus, menggunakan kartu BPJS Kesehatan selalu diterima dengan baik, tidak ada perbedaaan antara pasien umum dengan pasien BPJS Kesehatan, pengobatannya cepat sembuh, dengan menjadi peserta BPJS Kesehatan dapat rujukan pengobatan gratis di Surabaya.

\section{Peserta Selalu Memakai BPJS Kesehatan jika Menggunakan Pelayanan Kesehatan}

Berdasarkan wawancara mendalam yang dilakukan peneliti terhadap informan mengenai kebiasaan di tempat anda jika ingin menggunakan pelayanan kesehatan dengan BPJS Kesehatan diperoleh hasil lebih dari separuh informan mengatakan selalu pakai BPJS Kesehatan.Hasil analisis tema menggunakan aplikasi NVIVO terhadap jawaban Peserta BPJS Kesehatan diperoleh kata yang paling dominan adalah kata BPJS, kebiasaan, pakai, tempat, dan menggunakan. Adapun kebiasaan peserta selalu menggunakan BPJS Kesehatan sebagai jaminan kesehatannya tidak lepas dari asas manfaat yang telah terbukti dirasakan oleh peserta seperti tidak pernah dipungut biaya, pelayanan yang mudah dan cepat, dan tidak dibedakannya pasien BPJS Kesehatan dengan pasien umum. 


\section{Peserta Tidak Pernah Mendapatkan Informasi dari BPJS Kesehatan}

Berdasarkan wawancara mendalam yang dilakukan peneliti terhadap informan mengenai BPJS Kesehatan telah memberikan informasi tentang peraturan, dan hak dan kewajiban peserta BPJS Kesehatan, diperoleh hasil seluruh informan mengatakan tidak pernah mendapat informasi dari BPJS Kesehatan. Informasi yang mereka dapatkan paling banyak dari petugas kesehatan, kemudian kepala dusun, dan teman. Hasil analisis tema menggunakan aplikasi NVIVO terhadap jawaban Peserta BPJS Kesehatan diperoleh kata yang paling dominan adalah kata pernah, tidak, saya, dari, belum, dan informasi. Adapun informasi yang diterima perserta BPJS Kesehatan tentang BPJS Kesehatan berasal dari teman, keluarga, aparat desa, dan petugas kesehatan di daerah masing-masing. Informasi tersebut sepotong-sepotong, dan tidak menyeluruh, sehingga dapat menimbulkan penafsiranpenafsiran.

\section{Kondisi Fisik Tidak Menjadi Kendala untuk Memahami Peraturan BPJS Kesehatan}

Berdasarkan wawancara mendalam yang dilakukan peneliti terhadap informan mengenai kondisi fisik yang menjadi kendala untuk memahami peraturan BPJS Kesehatan diperoleh hasil lebih dari separuh peserta tidak ada kendala untuk memahami. Kalau pun ada kendala, peserta membawa pendamping untuk membantunya. Hasil analisis tema menggunakan aplikasi NVIVO terhadap jawaban Peserta BPJS Kesehatan diperoleh kata yang paling dominan adalah kata fisik, saya, tidak, ada, kesulitan, dan mengalami. Adapun peserta yang mengalami kendala seperti Ny.EA yang buta huruf dan matanya sedang sakit, serta Tn. MD yang kurang fasih berbahasa Indonesia, mereka selalu membawa pendamping untuk membantu mereka di pelayanan.

\section{Peserta Memiliki Pengalaman yang Baik Tentang BPJS Kesehatan}

Berdasarkan wawancara mendalam yang dilakukan peneliti terhadap informan mengenai pengalaman pribadi anda tentang BPJS Kesehatan diperoleh hasil seluruh informan memiliki pengalaman yang baik tentang BPJS Kesehatan. Hasil analisis tema menggunakan aplikasi NVIVO terhadap jawaban Peserta BPJS Kesehatan diperoleh kata yang paling dominan adalah kata BPJS, saya, kesehatan, pengalaman, anda, pribadi, dan baik. Adapun alasan peserta adalah meringankan biaya pengobatan, pelayanannya cepat dan tidak dipungut biaya, terjaminnya keberhasilan pengobatan, pernah menggunakan pelayanan gawat darurat di kota Jember dan dilayani, serta gratis.

\section{Rujukan Berjenjang, Ketidaksesuaian Kartu BPJS Kesehatan, dan Ketidaklengkapan Persyaratan Mendominasi Terjadinya Konflik antara Petugas Kesehatan dan Peserta BPJS Kesehatan}

Berdasarkan wawancara mendalam yang dilakukan peneliti terhadap informan dari petugas kesehatan Puskesmas Ganding, mengenai terjadinya konflik antara petugas kesehatan dengan peserta BPJS Kesehatan diperoleh hasil yang mendominasi terjadinya konflik antara petugas kesehatan dan peserta BPJS Kesehatan diantaranya adalah pelayanan rujukan berjenjang, ketidaksesuaian antara kartu BPJS Kesehatan dengan identitas diri yang dimiliki peserta, dan ketidaklengkapan persyaratan yang dibawa peserta BPJS Kesehatan.

\section{BPJS Kesehatan akan Melakukan Sosialisasi jika Diundang Datang}

Berdasarkan wawancara mendalam yang dilakukan peneliti terhadap informan dari BPJS Kesehatan mengenai kegiatan sosialisasi yang dilakukan oleh BPJS Kesehatan diperoleh hasil bahwa BPJS Kesehatan akan melakukan sosialisasi jika diundang datang untuk sosialisasi. Selain itu BPJS Kesehatan juga telah melakukan sosialisasi melalui media massa, radio, televisi, aplikasi android dan website remi mereka di www.bpjs-kesehatan.go.id. Namun rupanya hal itu belum tersentuh oleh peserta BPJS Kesehatan, sehingga mereka belum mengetahui tentang peraturan, pembiayaan, hak dan kewajiban peserta BPJS Kesehatan. Informasi yang didapat dari media massa seperti televisi dan media massa lainnya tidak didapat secara utuh sehingga masyarakat kebingungan kepada siapa dalam menanyakan maksud dan tujuan dari program BPJS Kesehatan tersebut.

\section{Sebagai Pelaku Usaha BPJS Kesehatan Berkewajiban Melakukan Sosialisasi}


Berdasarkan wawancara mendalam yang dilakukan peneliti terhadap informan dari seorang pakar hukum mengenai siapa yang berkewajiban melakukan sosialisasi tentang BPJS Kesehatan diperoleh hasil bahwa BPJS Kesehatan-lah yang berkewajiban untuk melakukan sosialisasi.

Menurut UU No. 08 tahun 1999 tentang Perlindungan Konsumen, BPJS Kesehatan sebagai pelaku usaha berkewajiban untuk memberikan informasi yang benar, jelas dan jujur mengenai kondisi dan jaminan barang dan/atau jasa serta memberi penjelasan penggunaan, perbaikan dan pemeliharaan. BPJS Kesehatan selaku penjamin pelayanan kesehatan harus memberikan informasi yang jelas, benar, jujur, dan terperinci perihal peraturan, pembiayaan, hak dan kewajiban peserta, sanksi jika terlambat membayar iuran, cara mendapatkan pelayanan, faskes tujuan, rujukan berjenjang, pelayanan gawat darurat, serta jenis pelayanan apa yang bisa dan tidak bisa ditanggung oleh BPJS Kesehatan. Sedangkan fasilitas kesehatan hanya terbatas pada pemberi pelayanan kesehatan, yaitu pelaksana dari kebijakankebijakan yang telah ditetapkan oleh BPJS Kesehatan.

\section{Peserta BPJS Kesehatan yang Merasa Dirugikan Dapat Mengajukan Pemberhentian dari Kepesertaan BPJS Kesehatan}

Berdasarkan wawancara mendalam yang dilakukan peneliti terhadap informan dari seorang pakar hukum mengenai bagaimana peserta yang merasa dirugikan setelah menjadi peserta BPJS Kesehatan diperoleh hasil, peserta BPJS Kesehatan dapat mengajukan pemberhentian dari kepesertaan BPJS Kesehatan. Hubungan antara BPJS Kesehatan dengan peserta BPJS Kesehatan tidak lepas dari adanya kesepakatan diantara keduanya. Dimana kesepakatan tersebut merupakan perjanjian antara kedua belah pihak untuk sepakat mengenai jaminan pelayanan kesehatan.

\section{Penduduk Indonesia Berhak untuk Memilih dan Menentukan Jaminan Kesehatan atau Asuransi Kesehatan yang Sesuai dan Cocok untuk Dirinya \\ Berdasarkan wawancara mendalam yang dilakukan peneliti terhadap informan dari seorang pakar hukum yaitu Tn. S mengenai bagaimana pendapat beliau perihal adanya pertentangan pasal dalam dalam Perpress}

No. 111 Tahun 2013 pasal 6 ayat 1 tentang JKN dengan UU No. 39 Tahun 1999 pasal 4, pasal 9 ayat 1, pasal 11, pasal 12 tentang Hak Asasi Manusia dan UU No. 08 tahun 1999 tentang Perlindungan Konsumen pasal 3 ayat c, pasal 4 ayat a dan b, diperoleh hasil bahwa peraturan perundangan yang dibawahnya tidak boleh bertentangan dengan peraturan perundangan yang di atasnya. Apabila dalam suatu peraturan terdapat pasal-pasal yang saling bertentangan satu dengan yang lainnya, maka norma secara hukum peraturan perundangan yang dibawahnya gugur secara hukum.

Adanya pertentangan pasal dalam dalam Perpress No. 111 Tahun 2013 pasal 6 ayat 1 tentang JKN dengan UU No. 39 Tahun 1999 pasal 4 , pasal 9 ayat 1 , pasal 11 , pasal 12 tentang Hak Asasi Manusia dan UU No. 08 tahun 1999 tentang Perlindungan Konsumen pasal 3 ayat c, pasal 4 ayat a dan b, akan mengakibatkan ketidakpastian hukum. Masyarakat akan menjadi bingung untuk tunduk dan patuh pada ketentuan pasal yang mana.

\section{PEMBAHASAN}

\section{Pemahaman tentang Aturan, Pembiayaan, Hak dan Kewajiban, Sanksi jika Terlambat Membayar Iuran, Cara Mendapatkan Pelayanan Kesehatan, dan kepada Siapa Menyampaikan Keluhan Peserta BPJS Kesehatan}

Berdasarkan paparan hasil penelitian, didapatkan bahwa masih banyak peserta BPJS Kesehatan yang belum paham mengenai peraturan, pembiayaan, hak dan kewajibannya, sanksi jika terlambat membayar iuran, faskes tujuan, rujukan berjenjang, pelayanan gawat darurat, cara menyampaikan keluhan, maupun perihal pelayanan kesehatan apa saja yang bisa dan tidak bisa didapatkan.

Kemudian peneliti melakukan konfirmasi terkait pemahaman peserta BPJS Kesehatan dengan petugas kesehatan di Puskesmas Ganding, peneliti melakukan wawancara dengan Ibu S beliau menjawab, "Banyak yang gak paham, kalo dijelaskan gak paham. Kalau pelayanan rawat jalannya lancar, tapi yang paling banyak masalah orang yang minta rujukan. Pada umumnya tidak sesuai prosedur BPJS, minta sendiri pasiennya minta dirujuk langsung. Saya jelaskan, harus sesuai prosedurnya BPJS kalau ingin gratis. Sering saya menemukan, namanya tidak sesuai, dibelakangnya tidak 
sesuai, KTP dan KK nya sesuai, KIS nya tidak sesuai, No. NIK ndak sama dengan KIS nya, sama saya suruh ke Kantor BPJS. Suruh cek dulu kalo kartu ini bener-benar milik orang ini. Yang nunggak, ada, tapi ndak banyak, paling satu atau dua orang, yang mandiri."

Kemudian peneliti juga melakukan konfirmasi ke pihak BPJS Kesehatan perihal pemahaman tentang hak dan kewajiban peserta, berikut penjelasan oleh Ibu AS yang diberikan disposisi oleh Ibu ELS untuk menjawab pertanyaan ini.

“Tergantung, karena gini, peserta kami itu terdiri dari banyak segmen, untuk segmen yang eee..., kita berbicara level pendidikan ya, level pendidikannya dia mengerti, itu biasanya mereka juga aktif bertanya ke kami, 'mbak yang menjadi hak saya apa dan yang menjadi kewajiban saya apa', dan itupun biasanya pasti kita jelaskan pada saat mereka awal mendaftar, tetapi ada kalanya yang dari segmen yang menengah ke bawah, yang rata-rata pendidikannya itu apa ya, tidak terlalu mengerti meskipun kami jelaskan biasanya mereka tetap tidak mengerti, biasanya seperti itu."

Kemudian peneliti menanyakan, apakah ada peserta yang mengadu ke BPJS Kesehatan perihal rujukan berjenjang? Bagaimana perspektif BPJS Kesehatan terhadap permasalahan tersebut?

"Kalau pengaduan banyak mas disini, itu menjadi PR kita bersama, tidak hanya BPJS saja, itu juga menjadi tanggung jawab bersama, baik itu Dinas Kesehatan, maupun fasilitas kesehatan itu sendiri."

Kemudian peneliti bertanya lagi perihal pelayanan kesehatan yang tidak dijamin oleh BPJS Kesehatan, bagaimana dengan pelayanan yang tidak dijamin oleh BPJS Kesehatan? Pernahkah BPJS mendapatkan kasus seperti itu? Contohnya seperti pelayanan estetika atau kosmetik yang ditolak?

"Pernah, kasus vitiligo, kalau sesuai Perpres No 19 tahun 2016 kan, termasuk di estetika, itu salah satu yang tidak dijamin oleh BPJS Kesehatan. Kita ngasih pengertian kepada pesertanya, kalau itu tidak dijamin oleh BPJS sesuai Perpress tadi.”

Pemahaman adalah tingkatan kemampuan yang mengharapkan seseorang mampu memahami arti atau konsep, situasi serta fakta yang diketahuinya. Dalam hal ini ia tidak hanya hafal secara verbalitas, tetapi memahami konsep dari masalah atau fakta yang ditanyakan, maka operasionalnya dapat membedakan, mengubah, mempersiapkan, menyajikan, mengatur, menginterpretasikan, menjelaskan, mendemonstrasikan, memberi contoh, memperkirakan, menentukan, dan mengambil keputusan (Galim Purwanto, 1997).

Menurut jurnal penelitian Bayu Kusuma Wardana (2017), tentang Hubungan Pendidikan dan Pengetahuan Peserta BPJS di Kelurahan Rowosari dengan Pemanfaatan Pelayanan Kesehatan di Puskesmas Rowosari, menunjukkan tingkat pengetahuan peserta BPJS (rendah dan tinggi) mempunyai hubungan yang signifikan terhadap pemanfaatan layanan kesehatan puskesmas $(p=0,001)$, dan tingkat pendidikan peserta BPJS mempunyai hubungan yang signifikan terhadap pemanfaatan layanan kesehatan puskesmas $(\mathrm{p}=0,017)$.

Kurangnya pemahaman peserta BPJS Kesehatan tentang hak dan kewajiban mereka disebabkan karena belum adanya penjelasan kepada mereka. Hal ini akan menjadi masalah di kemudian hari, karena masyarakat menggunakan BPJS Kesehatan dalam mendapatkan pelayanan kesehatan tanpa mengetahui dengan benar ketentuan dan peraturannya.

Tidak jarang ditemui mereka membuat penafsiran sendiri tentang pelayanan yang gratis, pelayanan yang segalanya dibolehkan dan ditanggung oleh BPJS Kesehatan. Padahal pelayanan yang gratis tersebut ada aturan mainnya dan petugas kesehatan-lah yang selalu menjadi sasaran mereka.

\section{Manfaat Menjadi Peserta BPJS Kesehatan}

Berdasarkan hasil penelitian yang dilakukan melalui wawancara oleh peneliti terhadap informan mengenai alasan anda ikut BPJS Kesehatan diperoleh hasil lebih dari separuh peserta mengatakan agar mengurangi biaya pengobatan pada saat sakit.

Jaminan Kesehatan adalah jaminan berupa perlindungan kesehatan agar peserta memperoleh manfaat pemeliharaan kesehatan dan perlindungan dalam memenuhi kebutuhan dasar kesehatan yang diberikan kepada setiap orang yang telah membayar iuran atau iurannya dibayar oleh pemerintah (Permenkes No. 71 tahun 2013 tentang Pelayanan Kesehatan pada JKN).

Setiap Peserta berhak memperoleh pelayanan kesehatan yang mencakup pelayanan promotif, preventif, kuratif, dan 
rehabilitatif termasuk pelayanan obat dan bahan medis habis pakai sesuai dengan kebutuhan medis yang diperlukan (Permenkes No. 71 tahun 2013 tentang Pelayanan Kesehatan pada JKN).

Dalam hal di suatu daerah belum tersedia Fasilitas Kesehatan yang memenuhi syarat guna memenuhi kebutuhan medis sejumlah Peserta, BPJS Kesehatan wajib memberikan kompensasi. Kompensasi dalam bentuk penggantian uang tunai sebagaimana dimaksud berupa penggantian atas biaya pelayanan kesehatan yang diberikan oleh Fasilitas Kesehatan yang tidak bekerja sama dengan BPJS Kesehatan. Besaran penggantian atas biaya pelayanan kesehatan sebagaimana dimaksud disetarakan dengan tarif Fasilitas Kesehatan di wilayah terdekat dengan memperhatikan tenaga kesehatan dan jenis pelayanan yang diberikan (Permenkes No. 71 tahun 2013 tentang Pelayanan Kesehatan pada JKN).

Menurut jurnal penelitian Debra S. S. Rumengan, J. M. L. Umboh, dan G. D. Kandou (2015), di Puskemas Paniki Bawah Kota Manado didapatkan hasil penelitian bahwa terdapat hubungan yang bermakna antara Persepsi tentang Jaminan Kesehatan Nasional (JKN) dengan Pemanfaatan Pelayanan Kesehatan di Puskesmas. Jika persepsi terhadap suatu program kurang baik maka dapat meningkatkan perilaku untuk tidak memanfaatkan puskesmas. Jika persepsi masyarakat terhadap suatu program kesehatan seperti JKN-BPJS adalah baik akan dapat mendorong masyarakat untuk memanfaatkannya dengan memilih tempat layanan kesehatan yang diberikan misalnya Puskesmas

Jawaban positif yang diberikan oleh peserta BPJS Kesehatan tidak lepas dari keberhasilan Puskesmas Ganding dalam melaksanakan Sistem Jaminan Kesehatan Nasional (SJKN) yang dilaksanakan dengan sebenarnya. Peserta BPJS Kesehatan telah merasakan asas manfaat dari berbagai pelayanan yang ditawarkan oleh pemerintah melalui fasilitas kesehatan yaitu Puskesmas Ganding.

\section{Alasan Kepuasan Menjadi Peserta BPJS Kesehatan}

Berdasarkan wawancara yang dilakukan peneliti terhadap informan mengenai kepuasan menjadi peserta BPJS Kesehatan diperoleh hasil hampir seluruh informan mengatakan puas menjadi peserta BPJS Kesehatan karena tidak dipungut biaya pada saat berobat, pelayanan yang cepat dan mudah, dan tidak ada perbedaan antara pasien umum dengan peserta BPJS.

Untuk mendapatkan data pembanding, peneliti melakukan wawancara dengan BPJS Kesehatan, perihal kepuasan peserta terhadap pelayanan BPJS Kesehatan. Penjelasan dilakukan oleh Ibu ZJ yang diberikan disposisi oleh Ibu ELS untuk menjawab pertanyaan ini.

"Jadi target kami adalah pertama kepuasan peserta, kepuasan peserta ini diuji melalui pihak ketiga yang berkunjung ke setiap kantor cabang BPJS Kesehatan diseluruh Indonesia melalui mistery guest, jadi kami tidak tahu kapan itu disurveynya, kapan itu datangnya, jadi kami tidak tahu. Nah untuk tahun ini capaian kepuasan peserta kami kalau tidak salah 86,5\%, tapi nanti saya buka dulu ya Mas Jun ya, nanti yang benar berapa, seingat saya $86,5 \%$. Kita termasuk ketiga se Jawa Timur, tapi untuk wilayah se Madura Raya ya, se Madura ini, Cabang Pamekasan."

Kepuasan (Satisfaction) adalah perasaan senang atau kecewa seseorang yang muncul setelah membandingkan kinerja (hasil) produk yang dipikirkan terhadap kinerja (atau hasil) yang diharapkan. Jika kinerja berada di bawah harapan maka pelanggan tidak puas. Jika kinerja memenuhi harapan maka pelanggan puas. Jika kinerja melebihi harapan maka pelanggan amat puas atau senang (Kotler 2006:177).

Menurut jurnal penelitian Fidela Firwan Firdaus dan Arlina Dewi (2014), tentang Evaluasi Kualitas Pelayanan terhadap Kepuasan Pasien Rawat Jalan Peserta BPJS di RSUD Panembahan Senopati Bantul, didapatkan hasil penelitian banyak hal yang mempengaruhi kepuasan pasien, antara lain pendaftaran lancar, waktu tunggu, pelayanan cepat, ramah, sopan, ketrampilan dan perawatan petugas medis bagus, profesional, ruangan bersih, fasilitas lengkap. Sebaliknya hal-hal yang mempengaruhi ketidakpuasan pasien, antara lain: karyawan pendaftaran datang terlambat, lambat, mengobrol sendiri, waktu tunggu lama, nada suara petugas medis tinggi, keramahan kurang, ruangan kurang luas, belum ada sekat, ruang tunggu kurang, jarak dari poli satu ke yang lain terlalu dekat, dan belum ada pengeras suara.

Kepuasan peserta BPJS Kesehatan bergantung kepada kualitas pelayanan yang diberikan oleh fasilitas kesehatan, yaitu Puskesmas Ganding. Hal ini disebabkan 
fasilitas kesehatan adalah pemberi layanan langsung terhadap peserta BPJS Kesehatan. Kelengkapan sarana dan prasarana yang ditawarkan, keterampilan, lama pelayanan, pelayanan yang tidak diskriminatif, sikap dan disiplin petugas kesehatan mempunyai nilai pengaruh besar terhadap kepuasan peserta BPJS Kesehatan.

\section{Informasi Sosialisasi dari BPJS Kesehatan}

Berdasarkan wawancara mendalam yang dilakukan peneliti terhadap informan mengenai sumber informasi tentang BPJS Kesehatan diperoleh hasil seluruh informan mengatakan tidak pernah mendapat informasi dari BPJS Kesehatan. Peserta BPJS Kesehatan hanya mendapatkan sedikit informasi perihal BPJS Kesehatan dari teman, keluarga, aparat desa, dan petugas kesehatan di daerah masing-masing.

Kemudian peneliti mengkonfirmasi informasi tersebut ke petugas kesehatan di Puskesmas Ganding, yaitu dengan Ibu S , "Ndak ada (sosialisasi), itu tok (survey), itu cuma disini aja (BP). Gak tahu saya kalau BPJS pernah menjelaskan cara penggunaan kartu, kalo cuma di rawat jalan ya itu aja (survey). Menjelaskan hak-hak kartunya saya gak pernah tahu. Saya tidak tahu kalau BPJS pernah mengadakan sosialisasi di instansi lain. Di puskesmas Ganding yang mengadakan sosialisasi hanya tenaganya sendiri (antar teman)."

Untuk mendapatkan informasi yang berimbang, peneliti kemudian menanyakan perihal permasalahan ini ke pihak BPJS Kesehatan, berikut penjelasan Ibu ZJ, beliau diberikan disposisi oleh Ibu ELS untuk menjawab pertanyaan tersebut.

"Kami juga ada program sosialisasi Mas Jun, jadi setiap tahunnya itu kami keliling ke tiap segmen ini, segmen pekerja penerima upah kami berikan sosialisasi, contohnya penerima pensiun, TNI, POLRI, terus juga di lingkungan Pemerintah PNS Pemkab Sumenep, Satker (Satuan Kerja) itu kami beri sosialisasi. Dimana ketika ada program Pemerintah Daerah, kita diundang, nah disitu kami berikan pemahaman tentang hak dan kewajibannya."

"Biasanya sosialisasi kita di kecamatan kalau yang PBI (Penerima Bantuan Iuran) lebih banyak di sana, kita juga masuk di kecamatan-kecamatan, kalau mereka mengundang kami untuk sosialisasi, kami pasti hadir disana."

"Ketika mereka ada program, kami menyampaikan, tolong pak kami juga dikabari. Ayo kami kolaborasi, dimana bapak ada kegiatan event mungkin atau apa, ataupun kami diberi waktu menyampaikan, kami siap."

Untuk mengetahui seberapa penting informasi ini harus disampaikan, peneliti melakukan wawancara dengan pakar hukum sebagai pembanding, beliau adalah Tn. S. Beliau adalah seorang notaris yang telah berpengalaman selama puluhan tahun, dan juga seorang dosen Fakultas Hukum di Universitas Wiraraja Sumenep.

"Sebelum pelaku usaha itu didaftarkan menjadi anggota BPJS, terlebih dahulu seharusnya itu, dari pihak BPJS itu harus ada sosialisasi dulu mengenai apa dan siapa BPJS itu. Kemudian apa hak dan kewajiban BPJS dengan peserta BPJS itu."

"BPJS itu selaku pelaku usaha, itu seharusnya melihat ketentuan undangundang perlindungan konsumen. Jadi dia itu selaku pelaku usaha, ada kewajibannya, yang disini (UU No. 36 tahun 1999 tentang Perlindungan Konsumen) harus ada antara lain harus beritikad baik dalam melakukan kegiatan usahanya, apa buktinya itikad baik? Ya itu tadi, sosialisasi masyarakat harus dipahami betul."

"Ini kewajiban dari pelaku usaha, harus memberikan informasi yang benar, jelas dan jujur, mengenai kondisi, jaminan barang atau produk, yang akan diberi (menjadi) hak dari peserta BPJS. Apakah informasinya sudah jelas, atau bagaimana."

Kegiatan sosialisasi merupakan kegiatan komunikasi, ini ditandai dengan adanya proses penyebaran pengetahuan dari seorang komunikator kepada komunikan dengan tujuan meningkatkan pengetahuan. Sosialisasi suatu program, merupakan pengetahuan yang disampaikan dalam suatu kegiatan sosialisasi yang berkaitan dengan konteks permasalahan yang dihadapi oleh masyarakat. Sosialisasi akan memegang peranan penting di dalam menyebarluaskan informasi yang berkaitan dengan inovasi atau pengetahuanpengetahuan yang berhubungan dengan inovasi, baik pengetahuan teknis maupun pengetahuan prinsip (Cangara, 2009).

Dalam teori George Edwards III dijelaskan bahwa komunikasi merupakan langkah awal dalam pelaksanaan kebijakan/program yang akan diberlakukan untuk mencapai sasaran. Tujuannya yaitu untuk pelaksanaan kebijakan/program yang lebih efektif dan terkontrol sebagaimana tujuan yang ditetapkan. Keberhasilan implementasi kebijakan 
mensyaratkan agar implementor mengetahui apa yang harus dilakukan, dimana yang menjadi tujuan dan sasaran kebijakan harus ditransmisikan kepada kelompok sasaran, sehingga akan mengurangi distorsi implementasi. Komunikasi dalam bentuk sosialisasi ini dilakukan agar masyarakat/peserta BPJS Kesehatan dapat lebih memahami hak dan kewajiban dari peserta BPJS Kesehatan. Komunikasi secara tidak langsung berupa media massa juga diberlakukan baik media elektronik dan media cetak. Media elektronik berupa website BPJS Kesehatan, televisi dan radio. Sedangkan media cetak berupa banner, spanduk, brosur, koran.

Menurut jurnal penelitian Nurul Innayah Dwi Putrie Ramadhani (2015), tentang Pengaruh Terpaan Sosialisasi Program Jaminan Kesehatan Nasional (JKN) terhadap Tingkat Pemahaman Karyawan The Sahid Rich Jogja Hotel, didapatkan hasil terdapat pengaruh positif dan signifikan terhadap sosialisasi langsung terhadap tingkat pemahaman.

Peserta BPJS Kesehatan masih banyak yang belum mendapatkan sosialisasi tentang Hak dan Kewajiban peserta BPJS Kesehatan sehingga informasi yang diterima oleh masyarakat terutama pada masyarakat yang tidak berpendidikan tinggi dan yang tinggal di daerah desa masih sangat minim. Hal ini dapat disebabkan karena BPJS Kesehatan melakukan sosialisasi secara pasif, yaitu harus diundang dulu untuk datang. BPJS Kesehatan tidak proaktif melakukan sosialisasi secara mandiri, melainkan menumpang di acara instansi lain. Selain itu informasi yang didapat dari media masa seperti televisi dan media massa lainnya tidak didapat secara utuh sehingga masyarakat kebingungan kepada siapa dalam menanyakan maksud dan tujuan dari program BPJS Kesehatan tersebut. Perlu diadakannya sosialisasi yang menyeluruh, sosialisasi yang menjelaskan tentang peraturan, pembiayaan, hak dan kewajibannya, sanksi jika terlambat membayar iuran, faskes tujuan, rujukan berjenjang, pelayanan gawat darurat, cara menyampaikan keluhan, maupun perihal pelayanan kesehatan apa saja yang bisa dan tidak bisa didapatkan. Dimana pada sosialisasi tersebut masyarakat dapat berdialog langsung dengan BPJS Kesehatan, dan bertanya perihal apa saja yang ingin mereka ketahui seputar BPJS Kesehatan.

\section{Pengalaman Pribadi, Pendapat Teman dan Keluarga, dan Minat terhadap BPJS Kesehatan}

Berdasarkan wawancara mendalam yang dilakukan peneliti terhadap informan mengenai pengalaman pribadi tentang BPJS Kesehatan diperoleh hasil seluruh informan memiliki pengalaman yang baik tentang BPJS Kesehatan. Begitu juga dengan pendapat teman atau keluarga tentang BPJS Kesehatan diperoleh hasil hampir seluruh informan menyatakan pelayanannya baik. Dan minat mereka untuk merekomendasikan atau mengajak teman atau keluarga untuk ikut BPJS Kesehatan diperoleh hasil lebih dari separuh informan berminat untuk mengajak teman atau keluarga untuk ikut BPJS Kesehatan.

Pengalaman dapat diartikan sebagai sesuatu yang pernah dialami, dijalani maupun dirasakan, baik sudah lama maupun yang baru saja terjadi (Mapp dalam Saparwati,2012). Pengalaman dapat diartikan juga sebagai memori episodik, yaitu memori yang menerima dan menyimpan peristiwa yang terjadi atau dialami individu pada waktu dan tempat tertantu, yang berfungsi sebagai referensi otobiografi (Bapistaet al,dalam Saparwati, 2012)

Menurut jurnal penelitian Rizky Octavia Zuhdy (2015), tentang Pengalaman Peserta JKN Terhadap Pelayanan BPJS di Kota Malang, didapatkan hasil bahwa pengalaman partisipan terhadap pelayanan BPJS mayoritas adalah sangat membantu dalam pelayanan kesehatan. Terdapat beberapa partisipan yang tidak puas akan kinerja BPJS dan berharap program kedepannya akan lebih baik lagi dalam memberikan pelayanan kesehatan.

Pengalaman merupakan salah satu cara peserta BPJS Kesehatan mendapatkan pengetahuan. Peserta BPJS Kesehatan yang memiliki pengalaman dalam mendapatkan pelayanan kesehatan sangat membantu dalam pelayanan kesehatan. Karena peserta tersebut memiliki tingkat kooperatif yang tinggi dengan petugas kesehatan, sehingga di pelayanan tidak ada kendala penundaan pelayanan kesehatan.

\section{KESIMPULAN}

1. Kurangnya pemahaman peserta BPJS Kesehatan disebabkan belum adanya informasi yang jelas, benar, terperinci dan detail perihal peraturan, pembiayaan, hak peserta dan kewajibannya. 
2. Faktor-faktor yang dapat mempengaruhi tingkat pemahaman peserta BPJS Kesehatan, antara lain belum adanya sosialisasi dari BPJS Kesehatan, belum ada sumber informasi yang benar dan jelas, kondisi fisik dan psikologis peserta, tingkat pendidikan peserta.

3. Alasan peserta ikut BPJS Kesehatan adalah untuk mengurangi biaya pengobatan.

4. Alasan puas menjadi peserta BPJS Kesehatan antara lain tidak dipungut biaya pada saat berobat, pelayanan yang cepat dan mudah, terjaminnya keberhasilan pengobatan, dan tidak ada perbedaan antara pasien umum dengan peserta BPJS.

5. Kepuasan peserta BPJS Kesehatan bergantung kepada kualitas pelayanan yang diberikan oleh fasilitas kesehatan, yaitu Puskesmas Ganding. Hal ini disebabkan fasilitas kesehatan adalah pemberi layanan langsung terhadap peserta BPJS Kesehatan

6. Pihak BPJS Kesehatan melakukan sosialisasi secara pasif, yaitu hanya melakukan sosialisasi jika diundang datang oleh pihak yang berkepentingan.

7. Informasi yang didapat dari media massa seperti televisi dan media massa lainnya tidak didapat secara utuh sehingga masyarakat kebingungan kepada siapa dalam menanyakan maksud dan tujuan dari program BPJS Kesehatan tersebut.

8. BPJS Kesehatan berkewajiban memberikan informasi dan sosialisasi yang jelas, benar, dan jujur perihal produk barang atau dan jasa yang akan diberikan, tidak boleh sampai menimbulkan penafsiran, harus jelas, terperinci, dan detail.

9. Peserta BPJS Kesehatan yang memiliki pengalaman dalam mendapatkan pelayanan kesehatan sangat membantu dalam pelayanan kesehatan. Karena peserta tersebut memiliki tingkat kooperatif yang tinggi dengan petugas kesehatan, sehingga di pelayanan tidak ada kendala penundaan pelayanan kesehatan.

\section{SARAN}

\section{Bagi BPJS Kesehatan}

1. BPJS Kesehatan perlu mengadakan peningkatan sosialisasi secara terusmenerus sampai di tingkat desa terkait peraturan, pembiayaan, hak peserta dan kewajiban peserta.
2. BPJS Kesehatan perlu mengadakan sosialisasi secara aktif dan mandiri, tanpa harus menunggu undangan dari pihak lain, agar tidak terjadi penafsiran sendiri-sendiri di masyarakat.

\section{Bagi Peserta BPJS Kesehatan}

1. Peserta BPJS Kesehatan agar mendapat informasi yang benar, jelas, terperinci dan detail terkait program layanan JKN BPJS Kesehatan dapat datang langsung ke kantor BPJS Kesehatan, atau call center BPJS Kesehatan 1500-400, atau lewat website www.bpjs-kesehatan.go.id , atau dapat mendownload aplikasi Mobile-JKN di Play Store.

2. Peserta BPJS Kesehatan tidak perlu raguragu dalam memanfaatkan pelayanan kesehatan di puskesmas sebagai layanan kesehatan yang utama dalam mendapat pertolongan kesehatan.

\section{Bagi Puskesmas Ganding dan Dinas Kesehatan}

Untuk meningkatkan persepsi masyarakat tentang Jaminan Kesehatan Nasional, diperlukan peningkatan kegiatan promosi kesehatan terkait pelayanan Jaminan Kesehatan Nasional - BPJS Kesehatan di Puskesmas secara kontinu, serta peningkatan kesadaran dan disiplin petugas kesehatan dalam melayani pasien dengan baik, serta memperhatikan etika dalam memberikan pelayanan kesehatan.

\section{DAFTAR PUSTAKA}

Arikunto, S. (2006). Prosedur Penelitian Suatu Pendekatan Praktik. Edisi Ke 6.

BPJS Kesehatan. (2014). Panduan Layanan Bagi Peserta BPJS Kesehatan. [Online]. Tersedia : https://bpjskesehatan.go.id/bpjs/dmdocuments/ 598b72db3c146fb9d466dee79262eca 4.pdf . (9 April 2017).

BPJS Kesehatan. (2014). Panduan Praktis Pelayanan Kesehatan. [Online]. Tersedia : https://bpjskesehatan.go.id/bpjs/dmdocuments/ a9c04aa825ffc12d24aeee668747f284 .pdf . (9 April 2017).

BPJS Kesehatan. (2014). Panduan Praktis Program Rujuk Balik Bagi Peserta JKN. [Online]. Tersedia: https://bpjskesehatan.go.id/bpjs/dmdocuments/ 4238e7d5f66ccef4ccd89883c46fcebc. pdf . (9 April 2017).

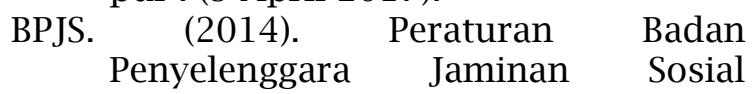


Kesehatan Nomor 1 tahun 2014 tentang Penyelenggaraan Jaminan Kesehatan.

Firdaus, Fidela F., Dewi, Arlina. (2014). EVALUASI KUALITAS PELAYANAN TERHADAP KEPUASAN PASIEN RAWAT JALAN PESERTA BPJS DI RSUD PANEMBAHAN SENOPATI BANTUL. Program studi Manajemen Rumah Sakit. Universitas Muhammadiyah Yogyakarta. Yogyakarta.

Imron, Moch. (2014). Metodologi Penelitian Bidang Kesehatan. Edisi ke-2. Jakarta : Sagung Seto.

Kementerian Kesehatan RI. (2013). Peraturan Menteri kesehatan Republik Indonesia Nomor 71 Tahun 2013 tentang Pelayanan Kesehatan pada Jaminan Kesehatan Nasional.

Kementerian Kesehatan RI. (2014). Peraturan Menteri Kesehatan Republik Indonesia No. 59 Tahun 2014 tentang Standar Tarif Pelayanan Kesehatan dalam Penyelenggaraan Program Jaminan Kesehatan.

Kementerian Kesehatan RI. (2014). Peraturan Menteri Kesehatan Republik Indonesia Nomor 28 Tahun 2014 tentang Pedoman Pelaksanaan Jaminan Kesehatan Nasional.

Laili, Nurfaidatil. (2014). Hubungan Sosialisasi Program BPJS Terhadap Pemahaman Tentang Hak Peserta BPJS Kesehatan Di RSUD Syarifah Ambami Rato Ebu Bangkalan. Jurnal Administrasi Publik. 31-35.

Notoatmodjo, S. (2003). Ilmu Kesehatan Masyarakat Prinsip-Pprinsip Dasar. Edisi Ke 2. Jakarta: PT. Rineka Cipta.

Notoatmodjo, S. (2003). Pendidikan dan Perilaku Kesehatan. Edisi Pertama. Jakarta: PT. Rineka Cipta.

Notoatmodjo, S. (2005). Metodologi Penelitian Kesehatan. Edisi Ke 3. Jakarta: PT. Rineka Cipta

Nursalam. (2003). Konsep \& Penerapan Metodologi Penelitian Ilmu Keperawatan : Pedoman Skripsi, Tesis dan Instrumen Penelitian Keperawatan. Edisi Pertama. Jakarta : Salemba Medika.

Prakoso, Sigit Budhi. (2015). Efektivitas Pelayanan Kesehatan BPJS Di Puskesmas Kecamatan Batang. Fakultas Ekonomi. Universitas Negeri Semarang. Semarang.
Presiden RI. (2004). Undang- Undang Nomor 40 Tahun 2004 Tentang Sistem Jaminan Sosial Nasional.

Presiden RI. (2011). Undang- Undang Nomor 24 Tahun 2011 Tentang Badan Penyelenggara Jaminan Sosial (BPJS).

Presiden RI. (2013). Peraturan Presiden Nomor 12 Tahun 2013 Tentang Jaminan Kesehatan.

Presiden RI. (2013). Peraturan Presiden Republik Indonesia Nomor 111 Tahun 2013 tentang Perubahan atas Peraturan Presiden Nomor 12 Tahun 2013 Tentang Jaminan Kesehatan.

Ramadhani, Nurul Innayah Dwi Putrie. (2015). PENGARUH TERPAAN SOSIALISASI PROGRAM Jaminan Kesehatan Nasional (Jkn) Terhadap Tingkat Pemahaman Karyawan. UPN "Veteran" Yogyakarta. http://eprints.upnyk.ac.id/7573/. (27 Januari 2018).

Rumengan, Debra S. S., Umboh, J. M. L., Kandou, G. D., (2015). Faktor-Faktor yang Berhubungan dengan Pemanfaatan Pelayanan Kesehatan Pada Peserta BPJS Kesehatan di Puskesmas Paniki Bawah Kecamatan Mapanget Kota Manado. Fakultas Kesehatan Masyarakat. Universitas Sam Ratulangi Manado. Manado.

Saepudin, Malik. (2011). Metodologi Penelitian Kesehatan Masyarakat. Edisi 1. Jakarta : CV. Trans Info Media.

Saryono dan Mekar Dwi Anggraeni. (2011). Metodologi Penelitian Kualitatif Dalam Bidang Kesehatan. Edisi Ke 2. Yogyakarta : Mulia Medika.

Saryono. (2011). Metodologi Penelitian Kesehatan PenuntunPraktis Bagi Pemula. Edisi Ke-4. Jogjakarta : Mitra Cendekia.

Setiawan, Dony HP dan Hendro Prasetyo. (2015). Metodologi Penelitian Kesehatan untuk Mahasiswa Kesehatan. Edisi 1. Yogyakarta : Graha Ilmu.

Sugiyono, P. (2007). Statika Untuk Penelitian. Edisi Ke 12. Bandung: CV. Alfabeta.

Suprapto, Maria Farida Indrati. (2005). Ilmu perundang-undangan : Proses dan Teknik Pembentukannya. Yogyakarta: Kanisius.

Ulinuha, Fuzna Elsa. (2014). Kepuasan Pasien Bpjs (Badan Penyelenggara Jaminan Sosial) Terhadap Pelayanan Di Unit Rawat Jalan (Urj) Rumah Sakit Permata Medika Semarang Tahun 
2014.

http://eprints.dinus.ac.id/6709/. (27 Januari 2018).

Wardana, Bayu Kusuma. (2016). Hubungan Pendidikan Dan Pengetahuan Peserta BPJS Di Kelurahan Rowosari Dengan Pemanfaatan Pelayanan Kesehatan Di Puskesmas Rowosari. Jurnal Kedokteran Diponegoro. Fakultas Kedokteran. Universitas Diponegoro. 48-52.

Widodo. (2017). Metodologi Penelitian Populer dan Praktis. Edisi 1. Kota Depok : PT. Rajagrafindo Persada.

Wijayanto, Wisnu Probo. (2017). Hubungan Pengetahuan dan Kemampuan Ekonomi Masyarakat Terhadap Aksesibilitas BPJS. Program Studi Ilmu Keperawatan. STIKES Aisyah Pringsewu. Lampung.

Zuhdi, Rizky Octavia. (2015). Pengalaman Peserta JKN Terhadap Pelayanan BPJS di Kota Malang. Fakultas Ilmu Kesehatan. Universitas Muhammadiyah Malang. Malang. 